or living in Eastern Europe) the number of subscribers would rise to around 800 , which would qualify for a $55 \%$ discount, making an annual subscription of around $£ 90$, compared with the present $£ 98$ if the member subscribes, or $£ 20(£ 15)$ if he does not. This assumed no resignations or withdrawals, and took no account of the more complex administrative arrangements which might lead to an increase in staffing levels, and therefore of the EASD membership content.

A pre-condition for any increase in the discount would be the signature of each member that the journal was for personal use and would not be handed over to the libraries of the respective departments.

Having heard argument and counter-argument, and taking into account that many younger members would be hard pressed to find the additional subscriptions involved, the General Assembly, whilst appreciating the reasons for the proposal, which they accepted in principle, decided against making subscription to Diabetologia mandatory for all members. Members were urged to subscribe to the journal if they did not already do so.

\section{Study groups and sub-committees}

Reports by the Chairmen or other Officers of the following Study Groups and Sub-committees were presented.

a) Postgraduate Education Sub-Committee

b) Diabetes Epidemiology Study Group

c) Diabetes Education Study Group

d) AIDSPIT Study Group

e) Nutrition Study Group

f) Control of Metabolism Study Group

The President ended the meeting by expressing his thanks to the reporting officers, and also to the retiring members of the Council, Drs Alberti, Crepaldi, Hanssen, Heding, Mincu and Raptis. The President welcomed the new members taking office, namely Dr. Ake Lernmark, the new Honorary Secretary and Drs. N. Bagriacik (Turkey), J.D. Baird (UK), P. Bratusch-Marrain (Austria), P. Brunnetti (Italy) and G. Petranyi (Hungary). In conclusion, Dr. Andreani reported that the Council had elected Dr. Baird as a Vice-President in succession to Dr. Heding.

\title{
Agenda for the 22nd General Assembly of the European Association for the Study of Diabetes, to be held in the Ergife Palace Hotel, Rome, Italy on Friday, 19 September 1986 at 11.30 a.m.
}

\author{
1. Minutes of 21st General \\ Assembly to be approved \\ 2. Reports
a) President
b) Honorary Treasurer
c) Honorary Auditors
d) Honorary Secretary e) Editor-in-Chief,
Diabetologia

Printed in Volume of Abstracts, and in Diabetologia, Vol 29, No. 8, 1986

3. Elections

Dr. D. Andreani

Dr. H. M.J. Krans

Drs. J. Ludvigsson and

J. N.C. Nuñes Correa

Dr. Å. Lernmark

Dr. M. Berger a) Council Members 1987-1990

In place of Drs. J-P. Felber, V.A. Koivisto, H.Orskov, G. Panzram and G. Slama retiring by rotation

b) Honorary Treasurer 1987-1990

c) Honorary Auditors 1987

In place of Dr. H.M.J. Krans, retiring by rotation

In place of Drs. J. Ludvigsson and J. N.C. Nuñes Correa, retiring by rotation
4. Study Groups

5. Any other business

6. Handing over of the Presidency 